\title{
SOIL AMENDMENT WITH Aerva javanica (Burm. f.) Juss. ex Schult. IN THE CONTROL OF ROOT ROT FUNGI OF COWPEA (Vigna unguiculata (L.) Walp.) AND MUNG BEAN [Vigna radiata (L.)]
}

\author{
Naheed Ikram, Shahnaz Dawar \\ Department of Botany, University of Karachi, Karachi - 75270, Pakistan. \\ e-mail: shahnaz_dawar@yahoo.com
}

Received: 15.032012

\begin{abstract}
Root rot fungi cause severe losses of crop plants, so the present work was carried out to determine the effect of Aerva javanica parts powder on root infecting fungi of mung bean (Vigna radiata (L.) and cowpea (Vigna unguiculata (L.) Walp.). A. javanica parts (stem, leaves and flower) were used as soil amendments at $0.1,1$ and $5 \%$ to check the effectiveness on growth parameters. All the plant parts showed a significant reduction in root rot fungi like Fusarium spp., Rhizoctonia solani Kuhn, and Macrophomina phaseolina (Tassi) Goid. It was noted that germination percentage, fresh weight, leaf area and number of nodules were significantly higher and the inhibitory effect on root rot fungi increased when the soil was amended with $A$. javanica leaves at $1 \%$. Thus, among all the treatments, A. javanica leaves at $1 \%$ were found to be the most effective against root rot fungi.
\end{abstract}

Key words: Aerva javanica, root rot fungi, mung bean, cowpea

\section{INTRODUCTION}

Biological treatments provide longer protection to the crop compared to fungicidal seed treatment. In addition, they offer benefits not obtainable with fungicidal seed protectants, especially the ability to colonize and protect the seed and germinating seedling (M u khopadhy a y, 1994). Root-rot diseases caused by soil-borne fungi are the most important diseases of many crops. Several fungi have been recorded as causal pathogens of root-rot and wilt diseases like Rhizoctonia solani and Fusarium solani (A bdallah , 1969; A b o u-zeid et al. 1990; A b o u - zeid et al. 1997). Fusarium wilt disease caused by pathogenic fungi, particularly the fungus Fusarium oxysporum, can cause severe losses in a wide variety of crop plants (Larkin and Fravel, 1998). Schroth and C o o k (1963) tested three bean varieties for variation in susceptibility to pre-emergence damping off caused by Rhizoctonia solani, Fusarium solani, and Pythium spp. as well as for the amount of seed exudation and they suggested that exudates influence the incidence of pre-emergence damping-off by providing fungi with nutritive substances necessary for germination and growth in soil. Gliotoxin is an immuno-suppressive cytotoxin produced by pathogenic fungal species (Grovel et al. 2006). Macrophomina phaseolina is the causal agent of charcoal root rot, a pathogen affecting agricultural and forest crops ( $\mathrm{S} \mathrm{h}$ a $\mathrm{n}$ e $\mathrm{r}$ et al. 1999), with more than 500 susceptible hosts (W y 11 i e et al. 1984).

Organic amendment is an important method for control of plant diseases. Organic amendments are generally used for the improvement of crop plants and increasing agricultural productivity. Various organic amendments have a suppressive effect on plant parasitic fungi and nematodes (A l a m, 1990). The method involves the amendment of different plant parts for the control of fungal and nematode diseases (M it a 1 and Gow sw a m i, 2001). Of the organic substrates, neem cakes have shown promising results in the control of root infecting fungi (A l a m, 1990; A b id et al. 1992). Organic amendments are generally used for improving crops, increasing agricultural productivity and suppressing soil-borne diseases ( $\mathrm{S}$ to ne et al. 2003). In a wide variety of organic matters that have been tested as organic amendments for managing plant pathogens, there are oil seed cakes which decreased the population of soilborne pathogens ( $\mathrm{S} \mathrm{h}$ a r m a et al. 1995). D a w a r et al. (2007) reported that sea weeds 
(Melanothanus afaqhusainii, Padina tetrastromatica, Cytoclonium purpuraeum and Hypnea valentiae) used alone or in combination with some bacteria (Rhizobium meliloti, Pseudomonas aeruginosa, Bacillus subtilis) significantly suppressed root-infecting fungi on mash bean and sunflower.

Aerva javanica grows under a wide range of climatic and edaphic conditions in its natural habitat. It commonly grows in the Karachi University campus. $\mathrm{S} \mathrm{h}$ a r if et al. (2011) isolated six natural products from the whole plant of Aerva javanica. Isoquercetrin (1), 5-methylmellein (2), 2-hydroxy-3-O- $\beta$-primeveroside naphthalene-1,4-dione (3), Apigenin 7-O-glucuronide (4), Kaempferol-3-O- $\beta$-D-glucopyranosyl-( $1 \rightarrow 2)-\alpha$-Lrhamno-pyranoside-7-O- $\alpha$-L-rhamnopyranoside (5), 7-(1 hydroxyethyl)-2-(2"- hydroxyethyl) -3,4-dihydrobenzopyran (6) the first time from Aerva javanica. Structural evidence was found by the extensive use of chemical and spectral studies. Different crude extracts ( $n$-hexane, chloroform, ethyl acetate, methanol and water) and all the known isolated compounds were tested for their antimicrobial activity and they displayed inhibitory activity. $\mathrm{Nabiel}$ et al (1990) introduced a new flavonol, isorhamnetin 3-O- $\beta$-[4 - $p$-coumaroyl$\alpha$-rhamnosyl $(1 \rightarrow 6)$ galactoside], from Aerva javanica along with its unacylated derivative, its kaempferol analogue and various common kaempferol, quercetin and isorhamnetin glycosides. Sh a rif et al. (2011) introduced Isoquercetrin, 5-methylmellein, apigenin 7-O-glucuronide from Aerva javanica var. javanica.

M a n o or et al. (2011) found that some species, including Abutilon spp., Aerva javanica, Capparis decidua, Cleome brachycarpa,Crotalaria burhia, Dipterygium glaucum, Gisekia pharnacioides and $\mathrm{Su}$ aeda fruticosa, could be used against intestinal worms due to their vermicidal and anthelmintic properties or against bacteria and other microorganisms due to their antimicrobial activity.

Chemical control of plant diseases has proved very effective, but the majority of these chemicals are highly expensive and exhibit lethal effects. The present study reports the effect of soil amendment with Aerva javanica in the control of root infection caused by $\mathrm{Fu}$ sarium spp., $R$. solani and $M$. phaseolina in mung bean and cowpea crops.

\section{MATERIALS AND METHODS}

Aerva javanica plant parts (stem, leaves and flower) were collected from the University of Karachi campus, air dried, ground in an electric blender, and stored in airtight bottles for further studies. The soil used was obtained from an experimental plot of the Department of Botany, University of Karachi. The sandy loam soil (containing sand, silt, clay in the propoertions of 70 ,
11 and $10 \%$ ) had the following properties: $\mathrm{pH}$ ranged from 7.1-9.65, moisture holding capacity (MHC) of $49 \%$ (K e e n and R a c z k ow ski, 1922), total nitrogen $0.077-0.099 \%$ (M ackenzie and Wallace, 1954), 3-7 sclerotia/g of M. phaseolina g-1 as found by wet sieving technique (Shei kh and $\mathrm{Gh}$ affar, 1975), 5-20\% of $R$. solani on sorghum seeds used as baits (W i 1 h e $1 \mathrm{~m}, 1955$ ), and Fusarium spp. $2000 \mathrm{cfu}$ $\mathrm{g}^{-1}$ as assessed by soil dilution technique ( $\mathrm{N}$ a s h and S y nde r, 1962). The soil was amended with Aerva javanica leaf, stem and flower powder at $0.1,1$ and $5 \% \mathrm{w} / \mathrm{w}$ and surface-sterilized seeds were sown in 8 $\mathrm{cm}$ diam. plastic pots, each containing $300 \mathrm{~g}$ of soil and watered regularly to maintain sufficient moisture required for the growth of plants. The pots were kept in a screen house in randomized complete block design with three replicates per treatment. Non-amended soil served as the control. The growth parameters such as shoot and root length and weight, leaf area, and number of nodules were recorded after 30 days of seed germination. To determine the incidence of root rot fungi, one $\mathrm{cm}$ long root pieces, after washing them in running tap water, were surface sterilized with $1 \% \mathrm{Ca}(\mathrm{OCl})_{2}$ and transferred on PDA plates supplemented with penicillin at $200 \mathrm{mg}$ and streptomycin at $200 \mathrm{mg} / \mathrm{liter}$, with 5 pieces per plate. Petri dishes were incubated at room temperature and after one week infection of roots by root-infecting fungi was recorded.

The data were subjected to analysis of variance (ANOVA) followed by the least significant difference (LSD) test at $\mathrm{P}=0.05$ and Duncan's multiple range test to compare treatment means ( $\mathrm{S}$ o k a l and Rohlf, 1995).

\section{RESULTS}

In the case of cowpea, when the soil was amended with A. javanica stem, leaf and flower powder at $0.1,1$ and $5 \% \mathrm{w} / \mathrm{w}$, there was $100 \%$ germination observed when the soil was amended with $A$. javanica stem and leaf powder at 0.1 and $1 \% \mathrm{w} / \mathrm{w}(\mathrm{P}<0.001)$, as compared to leaf and flower powder at $5 \%$. The soil amended with $A$. javanica leaves at $1 \%$ significantly enhanced shoot length and weight, in contrast to the soil amended with $A$. javanica stem and flower powder at 0.1 and $5 \%$. Root length and root weight significantly $(\mathrm{P}<0.05)$ increased when $A$. javanica leaves at $0.1 \%$ were applied to the soil, as compared to stem, leaf and flower powder at 1 and 5\% w/w. Leaf area was maximum when the soil was amended with A. javanica leaf powder at $1 \%$. Number of nodules was high when A. javanica leaf powder was applied to the soil at $1 \%$, in contrast to stem and flower powder at 0.1 and $5 \%$. Thus, we observed that $A$. javanica parts at $1 \%$ significantly enhanced all the growth parameters (Table 1). 
Table 1

Effect of soil amendment with Aerva stem, leaf and flower powder on growth parameters.

\begin{tabular}{|c|c|c|c|c|c|c|c|}
\hline \multicolumn{8}{|c|}{ COWPEA } \\
\hline Treatment & $\begin{array}{c}\text { Germination } \\
\%\end{array}$ & $\begin{array}{l}\text { Shoot length } \\
(\mathrm{cm})\end{array}$ & $\begin{array}{l}\text { Shoot weight } \\
\text { (gm) }\end{array}$ & $\begin{array}{l}\text { Root length } \\
\quad(\mathrm{cm})\end{array}$ & $\begin{array}{l}\text { Root weight } \\
\text { (gm) }\end{array}$ & $\begin{array}{l}\text { Leaf area } \\
\quad(\mathrm{cm})\end{array}$ & $\begin{array}{c}\text { Number of } \\
\text { nodules }\end{array}$ \\
\hline Control & $60.66 \pm 1.0$ & $10.00 \pm 0.9$ & $2.00 \pm 0.2$ & $5.00 \pm 0.1$ & $0.68 \pm 0.1$ & $9.330 \pm 0.5$ & $2 \pm 0.0$ \\
\hline $0.1 \%$ stem & $100.0 \pm 0.0$ & $11.32 \pm 0.5$ & $2.49 \pm 0.4$ & $6.66 \pm 1.7$ & $0.84 \pm 0.2$ & $14.91 \pm 1.9$ & $5 \pm 1.5$ \\
\hline $1 \%$ stem & $100.0 \pm 0.0$ & $11.10 \pm 0.9$ & $2.24 \pm 0.2$ & $5.44 \pm 0.3$ & $0.82 \pm 0.0$ & $14.87 \pm 0.3$ & $5 \pm 0.6$ \\
\hline $5 \%$ stem & $100.0 \pm 0.0$ & $12.05 \pm 0.7$ & $2.07 \pm 0.2$ & $6.00 \pm 0.8$ & $0.90 \pm 0.4$ & $14.31 \pm 2.5$ & $5 \pm 0.3$ \\
\hline $0.1 \%$ leaves & $86.66 \pm 1.1$ & $11.11 \pm 1.0$ & $2.18 \pm 0.1$ & $6.66 \pm 1.4$ & $0.99 \pm 0.3$ & $11.68 \pm 2.2$ & $6 \pm 0.3$ \\
\hline $1 \%$ leaves & $100.0 \pm 0.0$ & $12.21 \pm 1.7$ & $2.99 \pm 0.7$ & $5.96 \pm 0.6$ & $1.00 \pm 0.1$ & $13.85 \pm 1.4$ & $6 \pm 1.3$ \\
\hline 5\%leaves & $6.666 \pm 1.0$ & $9.000 \pm 5.1$ & $2.08 \pm 1.3$ & $5.00 \pm 4.6$ & $0.24 \pm 0.4$ & $13.00 \pm 7.7$ & $3 \pm 1.7$ \\
\hline $0.1 \%$ flower & $100.0 \pm 0.0$ & $10.83 \pm 2.6$ & $2.03 \pm 0.3$ & $6.13 \pm 0.6$ & $0.71 \pm 0.3$ & $11.72 \pm 0.6$ & $7 \pm 0.6$ \\
\hline $1 \%$ flower & $100.0 \pm 0.0$ & $11.63 \pm 1.2$ & $2.29 \pm 0.3$ & $5.55 \pm 1.7$ & $1.12 \pm 0.5$ & $13.57 \pm 4.2$ & $5 \pm 1.1$ \\
\hline $5 \%$ flower & $6.666 \pm 1.1$ & $10.00 \pm 5.7$ & $1.96 \pm 1.1$ & $1.66 \pm 2.8$ & $0.27 \pm 0.4$ & $9.290 \pm 5.3$ & $3 \pm 1.7$ \\
\hline $\mathrm{LSD}=0.05$ & 21.99 & 5.318 & 1.40 & 3.00 & 0.54 & 4.712 & 3.00 \\
\hline \multicolumn{8}{|c|}{ MUNG BEAN } \\
\hline Treatments & $\begin{array}{c}\text { Germination } \\
\%\end{array}$ & $\begin{array}{l}\text { Shoot length } \\
(\mathrm{cm})\end{array}$ & $\begin{array}{l}\text { Shoot weight } \\
\text { (gm) }\end{array}$ & $\begin{array}{l}\text { Root length } \\
\quad(\mathrm{cm})\end{array}$ & $\begin{array}{l}\text { Root weight } \\
\text { (gm) }\end{array}$ & $\begin{array}{l}\text { Leaf area } \\
\qquad(\mathrm{cm})\end{array}$ & $\begin{array}{c}\text { Number of } \\
\text { nodules }\end{array}$ \\
\hline Control & $80.0 \pm 1.0$ & $9.000 \pm 0.6$ & $0.60 \pm 0.1$ & $4.00 \pm 1.0$ & $0.19 \pm 0.1$ & $4.00 \pm 1.4$ & $2 \pm 0.1$ \\
\hline $0.1 \%$ stem & $100 \pm 0.0$ & $13.32 \pm 1.5$ & $0.63 \pm 0.0$ & $6.33 \pm 0.5$ & $0.26 \pm 0.0$ & $5.26 \pm 0.8$ & $5 \pm 0.9$ \\
\hline $1 \%$ stem & $100 \pm 1.1$ & $12.66 \pm 1.8$ & $0.72 \pm 0.2$ & $6.66 \pm 1.2$ & $0.36 \pm 0.0$ & $7.04 \pm 2.2$ & $5 \pm 0.1$ \\
\hline $5 \%$ stem & $13.3 \pm 1.5$ & $9.555 \pm 8.0$ & $0.61 \pm 0.4$ & $4.00 \pm 3.2$ & $0.22 \pm 0.1$ & $3.91 \pm 3.6$ & $4 \pm 3.1$ \\
\hline $0.1 \%$ leaves & $100 \pm 0.0$ & $13.44 \pm 1.1$ & $0.85 \pm 0.0$ & $5.61 \pm 1.3$ & $0.28 \pm 0.0$ & $7.06 \pm 1.5$ & $6 \pm 0.7$ \\
\hline $1 \%$ leaves & $100 \pm 0.0$ & $13.44 \pm 0.8$ & $0.72 \pm 0.1$ & $7.44 \pm 0.0$ & $0.27 \pm 0.0$ & $6.13 \pm 1.1$ & $5 \pm 0.3$ \\
\hline $5 \%$ leaves & $33.3 \pm 2.3$ & $10.77 \pm 1.9$ & $0.52 \pm 0.4$ & $3.44 \pm 0.5$ & $0.27 \pm 0.1$ & $5.00 \pm 2.7$ & $4 \pm 0.5$ \\
\hline $0.1 \%$ flower & $100 \pm 2.0$ & $12.60 \pm 2.7$ & $0.74 \pm 0.2$ & $5.00 \pm 3.4$ & $0.33 \pm 0.0$ & $6.08 \pm 1.3$ & $7 \pm 2.8$ \\
\hline $1 \%$ flower & $100 \pm 2.0$ & $11.16 \pm 1.0$ & $0.77 \pm 0.0$ & $7.36 \pm 1.5$ & $0.32 \pm 0.0$ & $6.66 \pm 1.0$ & $5 \pm 1.2$ \\
\hline $5 \%$ flower & $33.3 \pm 2.3$ & $11.16 \pm 0.5$ & $0.84 \pm 0.2$ & $5.66 \pm 0.7$ & $0.40 \pm 0.0$ & $5.32 \pm 1.3$ & $3 \pm 1.3$ \\
\hline $\mathrm{LSD}=0.05$ & 26.16 & 5.65 & 0.40 & 3.06 & 0.19 & 3.18 & 2.68 \\
\hline
\end{tabular}

There was a significant reduction in root-infecting fungi such as $R$. solani, M. phaseolina and Fusarium spp. Fusarium spp. was significantly suppressed when the soil was amended with A. javanica stem powder at $5 \%(\mathrm{P}<0.001)$. $R$. solani infection was significantly reduced by $6.66 \%$ from $100 \%$ when the soil was amended with A. javanica leaf powder at $1 \%$ $(\mathrm{P}<0.001)$. Infection of $M$. phaseolina was highly reduced when A. javanica leaf powder was applied to the soil at $1 \%(\mathrm{P}<0.001)$ (Table 2$)$.

Germination percentage of mung bean seeds significantly increased when soil was amended with A. javanica stem, leaf and flower powder at $1 \% \mathrm{w} / \mathrm{w}$ $(\mathrm{P}<0.001)$. Fresh weight and length of plants were maximum when $A$. javanica leaf powder mix was added to the soil at $1 \% \mathrm{w} / \mathrm{w}$. Root length and weight were high when A. javanica leaf powder mix was applied to the soil at at $1 \% \mathrm{w} / \mathrm{w}$. Leaf area of plants was greater when the soil was amended with A. javanica leaves at $0.1 \% \mathrm{w} / \mathrm{w}$. Number of nodules per plant was maximum when flower powder was applied to the soil at $0.1 \% \mathrm{w} / \mathrm{w}$. Mung bean plants had the highest height and weight when $A$. javanica leaf powder was added to the soil at 0.1 and $1 \% \mathrm{w} / \mathrm{w}$, in contrast to A. javanica stem and leaf powder at $5 \% \mathrm{w} / \mathrm{w}$ (Table 1).

Root-infecting fungi, such as R. solani, M. phaseolina and Fusarium spp., were significantly reduced when A. javanica powder was applied to the soil at $0.1,1$ and $5 \%$ w/w. Fusarium spp. infection was significantly reduced when the soil was amended with A. javanica leaf powder at $1 \% \mathrm{w} / \mathrm{w}(\mathrm{P}<0.001)$. Infection of $R$. solani decreased when A. javanica leaf powder was applied to the soil soil at $1 \% \mathrm{w} / \mathrm{w}(\mathrm{P}<0.001)$. There was significant suppression of $M$. phaseolina when A. javanica leaf powder was added to the soil at $1 \%$ $\mathrm{w} / \mathrm{w}(\mathrm{P}<0.001)$ (Table 2). 
Table 2

Effect of soil amendment with Aerva

stem, leaf and flower in the control of root rot fungi of mung bean and cowpea.

\begin{tabular}{|c|c|c|c|}
\hline \multicolumn{4}{|c|}{ COWPEA } \\
\hline Treatment & Fusarium spp. & R. solani & M. phaseolina \\
\hline Control & $100.0 \pm 1.0$ & $100.0 \pm 0.0$ & $77.66 \pm 4.0$ \\
\hline $0.1 \%$ stem & $28.66 \pm 1.0$ & $42.00 \pm 3.4$ & $26.33 \pm 6.5$ \\
\hline $1 \%$ stem & $19.88 \pm 1.3$ & $52.66 \pm 1.1$ & $24.44 \pm 7.6$ \\
\hline $5 \%$ stem & $11.11 \pm 1.0$ & $15.55 \pm 7.7$ & $11.10 \pm 7.7$ \\
\hline $0.1 \%$ leaves & $35.32 \pm 1.3$ & $15.22 \pm 9.8$ & $15.22 \pm 9.8$ \\
\hline $1 \%$ leaves & $16.00 \pm 1.9$ & $6.666 \pm 1.1$ & $6.666 \pm 1.1$ \\
\hline $5 \%$ leaves & $22.22 \pm 3.8$ & $13.10 \pm 1.1$ & $11.11 \pm 3.8$ \\
\hline $0.1 \%$ flower & $30.66 \pm 1.3$ & $8.777 \pm 3.6$ & $17.55 \pm 9.8$ \\
\hline $1 \%$ flower & $31.11 \pm 0.0$ & $10.99 \pm 3.7$ & $15.55 \pm 3.8$ \\
\hline $5 \%$ flower & $44.44 \pm 7.6$ & $40.90 \pm 7.6$ & $22.20 \pm 3.8$ \\
\hline $\mathrm{LSD}=0.05$ & 20.19 & 16.96 & 13.61 \\
\hline \multicolumn{4}{|c|}{ MUNG BEAN } \\
\hline Treatments & Fusarium spp. & R. solani & M. phaseolina \\
\hline Control & $100.0 \pm 1.0$ & $100.0 \pm 1.1$ & $100.0 \pm 0.9$ \\
\hline $0.1 \%$ stem & $35.11 \pm 1.1$ & $55.00 \pm 2.5$ & $37.55 \pm 7.3$ \\
\hline $1 \%$ stem & $30.88 \pm 4.2$ & $46.00 \pm 1.1$ & $30.88 \pm 1.6$ \\
\hline $5 \%$ stem & $19.77 \pm 6.3$ & $24.00 \pm 1.0$ & $15.33 \pm 9.8$ \\
\hline $0.1 \%$ leaves & $53.11 \pm 1.7$ & $44.00 \pm 3.4$ & $15.55 \pm 3.8$ \\
\hline 1\%leaves & $11.11 \pm 1.5$ & $13.00 \pm 7.0$ & $13.33 \pm 6.6$ \\
\hline $5 \%$ leaves & $24.22 \pm 1.8$ & $33.11 \pm 2.4$ & $13.10 \pm 1.6$ \\
\hline $0.1 \%$ flower & $17.77 \pm 3.8$ & $31.11 \pm 1.0$ & $37.33 \pm 2.5$ \\
\hline $1 \%$ flower & $19.77 \pm 6.3$ & $33.22 \pm 1.9$ & $19.99 \pm 1.7$ \\
\hline $5 \%$ flower & $37.33 \pm 1.2$ & $33.11 \pm 1.3$ & $35.44 \pm 2.0$ \\
\hline $\mathrm{LSD}=0.05$ & 19.216 & 23.065 & 22.066 \\
\hline
\end{tabular}

\section{DISCUSSION}

The present observations showed that soil amendment with $A$. javanica enhanced the plant growth and reduced the infection by pathogenic fungi like Fusarium spp., R. solani and M. phaseolina. Infection by $M$. phaseolina was significantly reduced on mung bean and cowpea when the plant powder was used at $0.1,1$ and 5\% w/w. Similarly, Eucalyptus sp. leaf, stem, bark and fruit powder has the potential to reduce infection caused by root-infecting fungi, viz. Fusarium sp., R.solani and M. phaseolina. (D a w a r et al. 2007). Neem cake has shown promising results in the control of root-infecting fungi (A l a m, 1990; A bid et al. 1992). Tariq et al. (2006) used different parts of Avicennia marina, viz. leaves, stems and pneumatophores, for the control of root-infecting fungi. Eucalyptus essential oil is considered to have marked antiseptic activity against infectious bacteria, viruses and fungi (I n o u y e et al. 2001). $\mathrm{Za} \mathrm{in} \mathrm{a} \mathrm{b} \mathrm{et}$ al. (2009) reported that seed powder of Azadirachta in- dica, Adenanthera pavonina, Leucaena leucocephala, and Eucalyptus spp. control root rot diseases and the application of A. pavonina, L. leucocephala and Eucalyptus spp. at 0.1 and $1 \% \mathrm{w} / \mathrm{w}$ showed significant control of root rot fungi.

M. phaseolina, which produces charcoal rot disease in plants, is reported to be suppressed by Avicennia marina plant parts like leaves, stem and pneumatophore when soil is amended at $5 \% \mathrm{w} / \mathrm{w}$ in the case of okra and mash bean plants (T a r i q et al. 2006, 2008). S u r a t u z z a m an (1995) observed an excellent inhibitory effect of Allium sativum and Zingiber officinale on soybean seeds to control seed-borne fungi, namely Colletotrichum dematium var. truncatum, Macrophomina phaseolina and Colletotrichum kikucchii. Soil amendments with biochar provide high surface area and the porosity of biochar enables it to adsorb or retain nutrients and water, and they also provide a habitat for beneficial microorganisms to flourish $(\mathrm{G} 1$ a s e $\mathrm{r}$ et al. 2002; Le hmann and Rondon, 2006; W ar n o c k et al. 2007). 
The valuable medicinal properties of different plants are due to the presence of several constituents i.e. saponins, tannins, alkaloids, alkenyl phenols, glycoalkaloids, flavonoids, sesquiterpenes lactones, terpenoids and phorbol esters ( $\mathrm{Tiw}$ ari and $\mathrm{Singh}$, 2004). Natural chemicals and their use for plant protection is one of the focuses of the research all over the world (K i r a n et al. 2006).

\section{CONCLUSION}

Soil amendment with A. javanica needs to be introduced into fields on a larger scale. It can therefore be suggested that such soil amendments could represent an environmentally friendly strategy for controlling soilborne pathogens as a substitute for chemical fungicides.

\section{REFRENCES}

Abdallah A.M.A. 1969. Studies on root diseases of broad bean in Egypt. M.Sc. Thesis, Fac. Agric., Shams University.

Abid M., Ehtheshamul-Haque S., Maqbool M.A., Ghaffar A. 1992. Effect of oil cakes, Bradyrhizobium sp., Paecilomyces lilacinus and furdan on root nodulation and root-knot nematodes in mung bean. Pak. J. Nematol.10: 145-150.

Abou-Zeid N.M., E1-Morsy G.A., Hassanein A.M., Arafa M.K. 1997. Major organisms causing root-rot, wilt and their relative importance on faba bean, lentil and chickpea. Egypt. J. Agri. Res.75(3): 529-542.

Abouzeid N.M., E1-Waki A.A., E1-Sherif I.M., A mer M.I. 1990. Studies on root-rot and wilt of lentil and their control. Agric. Res. 68: 421-429.

A la m M. 1990. Neem in nematode biocontrol (Aspects and prospects): M.S. Jairajpuri, M.M. Alam and I. Ahmed. BS Publishers and Distributors (Pvt) Ltd. Dehli-110032, India. 51-55.

Dawar S., Younus S. M., Tariq M., Zaki M.J. 2007. Use of Eucalyptus in the control of root infecting fungi on mung bean and chick pea. Pak. J. Bot. 39(3):975-979.

Glaser B., Lehmann J., Zech W.2002. Ameliorating physical and chemical properties of highly weathered soils in the tropics with charcoal biology and fertility of soils. 35:219-230.

Grovel O., Kerzaon I., Petit K., Dupont T.E., Pouchus Y. 2006. A new and rapid bioassay for the detection of gliotoxin and related epipolythiodioxopiperazines produced by fungi. 66(2):286-93.

Hussain S., Ghaffar A., Aslarn M. 1990. Biological control of Macrophomina phaseolina charcoal rot of sunflower and mungbean. J. Phytopathology, 130: 157-160.

Inouye S., T. Takizawa and Yamaguchi 2001. Antibacterial activity of essential oil and their major constituents against respiratory tract pathogens by gaseous contact. J.Antimicrobial chemotherapy, 47: 565573.

Keen B.A., Raczkowski H. 1992. The relation between clay content and certain physical properties of soil. J. Agric. Sci. 11: 441-449.

Kiran K., Linguraju S., Adiver S. 2006. Effect of plant extract on Sclerotium rolfsii, the incitant. of stem rot of ground nut. J. Mycol. Pl. Pathol. 36: 77-79.

Larkin R.R., Fravel D.R. 1998. Efficiency of various fungal and bacterial biocontrol organisms for control of fusarium wilt of tomato. Plant Diseases, 82:1022-1028.

Lehmann J., Rondon M. 2006. Bio char soil management on highly weathered soils in the humid tropics. In: N. Uphoff et al. (eds.), Biological approaches to sustainable soil systems. Florida: CRC Press, Taylor and Francis Group. P. 517-530.

Mackenzie H.A., Wallace H.S. 1954. The Kjeldahl determination of nitrogen. A critical study of digestion conditions, temperature, catalyst and oxidizing agents. Aust. J.Chem. 7: 55-70.

Mansoor H., Muhammad A., Al-quriany F., Tahir N., Muhammad S., Aqeel A., Ad$\mathrm{n}$ a n Y., Narg is N.2011. Medicinal flora of cholistan desert a review Pak J. Bot. 43:39-50.

Mital A., Gowswami B.K. 2001. Role of undioil seed cake for the management of disease complex caused by Fusarium solani and Meloidogyne incognita on brinjal. Pak. j. Nematol. 19: 87-90.

Mukhopadhyay A.N. 1994. Biocontrol of soil borne fungal plant pathogens current status, future prospect and potential limitations. Indian Phytopathology. 47(2): 1 19-126.

Nabiel A.M., Mansour M.A, Markham K.R. 1990. An acylated isorhamnetin glycoside from Aerva javanica National research centre Dokki Egypt Phytochemistry, 29 (4) 1344-1345.

Nash S.M., Snyder W.C. 1962. Quantitative estimation by plate count of propagules of the bean root rot fungus Fusarium in field soil. Phytopathology. $52: 567-572$.

Schroth M.N., Cook M.J. 1963. Seed exudation and influence on pre-emergence damping-off of bean. Phytopathology. 53: 620-623.

Shahwar D., Abid M., Rehman A.U., Maqbool M.A., Chaudhary M.I. 1994. Nematicidal constituents of Datura fastuosa. pp 284-285.

Shaner G., Abney S., Scott D. 1999. Charcoal rot of soybeans. Purdue University. Department of Botany and Plant Pathology.

Sharif A., Ahmed E., Malik A., Mukhtar U. H., Munawar M.A, Farrukh A., Nagra S.A., Anwar J., Ashraf M., Mahmood Z. 2011. Antimicrobial constituents from multiplication on different substrates in the control of root rot fungi. Int. J. Biol. Biotech.

Sharma S.K., Aggarwal R.K., Lodha S. 1995. Population changes of Macrophomina phaseolina and 
Fusarium oxysporum f. sp. cumini in oil-cake and crop residue amended sandy soils. Applied Soil Ecology. 2(4): 281-284

Sheikh A.H., Ghaffar A. 1975. Population study of sclerotia of Macrophomina phaseolina in cotton fields. Pak. J. Bot. 7: 13-17.

Sokal R.R., Rohlf F.J. 1995. Biometry: The principles and practices of statistics in biological research freeman, New York. pp. 887

Stone A.G., Vallad G.E., Cooperband L.R., Rotenburg D.R., Darby H.M., Stevenson W.R., Goodman R.M. 2003. Impact of annual organic amendment on disease incidence in a three year vegetable rotation. Plant Disease. 87: 1037-1042.

Suratuzzaman M., Islam M.R., Hossain I. 1995. Effect of plant extracts and chemicals in controlling seed borne fungi of soybean. Progress. Agric. 1: 39-42.

Tariq M., Dawar S., Mehdi F.S., Zaki M.J. 2006. Use of Avicennia marina in the control of root infecting fungi on okra and mash bean. Pak. J. Bot. 38 (3): 811-815.

Tariq M., Dawar S., Mehdi F.S., Zaki M.J. 2008. The effect of mangroves amendments to soil on root rot and root knot of potato (Solanum tuberosum L.) Acta Agrobot. 61 (1): 115-121.

Tiwar S., Singh A. 2004. Toxic and sub-lethal effects of oleadrin on biochemical parameters of freshwater air breathing murrel, Chant punctatus (Bloch.). Indian J. Exp. Biol. 42: 413-418.

Warnock D.D., Lehmann J., Kuyper T.W., Rillig M.C. 2007. Mycorrhizal responses to biochar in soil concepts and mechanisms. Plant Soil 300:9-20.

Wilhel m S. 1955. Longevity of the Verticillium wilt fungus in the laboratory and field Phytophathology. 45: 180181.

Wyllie T., Gangopadhyay S., Teague W., Blanchar R. 1984.Germination and production of Macrophomina phaseolina microsclerotia as affected by oxygen and carbon dioxide concentration. Res. J. Agric. Biol. Sci. 2(6): 391-398,

Zaniab M.A., Shahnaz D., Marium T.2009 Fungicidal potational of some local tree seeds for controlling root rot disease. Pak. J. Bot. 41(3):1439-1444.

\section{Wzbogacanie gleby poprzez zastosowanie Aerva javanica (Burm. f.) Juss. ex Schult. w zwalczaniu grzybów powodujących zgniliznę korzeni wspięgi chińskiej (Vigna unguiculata (L.) Walp.) oraz fasoli mung (Vigna radiata (L.)}

\section{Streszczenie}

Grzyby powodujące zgniliznę korzeni przynoszą poważne straty roślin uprawnych, dlatego przeprowadzono badania w celu określenia wpływu sproszkowanych z części roślin Aerva javanica na grzyby porażające korzenie fasoli mung (Vigna radiata (L.) oraz wspięgi chińskiej (Vigna unguiculata (L.) Walp.). Części roślin A. javanica (łodyga, liście oraz kwiaty) zastosowano jako dodatki wzbogacające glebę w proporcjach $0,1,1$ oraz $5 \%$ w celu sprawdzenia ich efektywności w odniesieniu do parametrów wzrostu roślin. Wszystkie części roślin wykazywały znacznie zmniejszenie obecności grzybów wywołujących zgniliznę korzeni, takich jak Fusarium spp., Rhizoctonia solani Kuhn i Macrophomina phaseolina (Tassi) Goid. Zanotowano, że procent kiełkowania, świeża masa, powierzchnia liści oraz liczba brodawek były istotnie wyższe, jak również wzrosło działanie hamujące na grzyby powodujące zgniliznę, kiedy gleba została wzbogacona proszkiem z liści A. javanica w proporcji 1\%. Stwierdzono, że spośród wszystkich kombinacji doświadczalnych liście $A$. javanica zastosowane na poziomie $1 \%$ były najbardziej skuteczne w zwalczaniu grzybów wywołujących zgniliznę korzeni. 